\title{
Betwixt "the Wise Man and the Prince": A Partnership in Comity and Conciliation for the South China Sea Disputes
}

\author{
Mary George $^{* *} \&$ Anneliz R. George ${ }^{* * *}$
}

In a region fraught with tensions and conflicts, the South China Sea Arbitral Award Case (Case) concerned maritime conflicts between the Philippines and China, an inter-State, non-consensual, ex-parte arbitration under Annex VII of the UN Law of the Sea Convention (UNCLOS). The Case went against China. The Annex VII Tribunal decision of first and last instance, was final and without appeal. However, to the authors, the Case drew attention to the inherently unfair provisions of an exparte hearing under Annex VII that violates the principle of natural justice and casts uncertainty on the role and future of mandatory conciliation under the UNCLOS. These omissions are addressed here. Noting these omissions and limitations, to restore regional goodwill, ameliorate conflicts and tensions, and promote dispute settlement, a solution in mandatory conciliation is proposed - A Partnership in Comity and Conciliation for the South China Sea”- with its provenance rooted in international law.

* The research was partly supported by University of Malaya Research Grant, Equitable Society Cluster No RP049A17SBS, Equitable Legal Order in the South China Sea: the SCS Arbitral Tribunal, the International Court of Justice (ICJ), and the International Tribunal for the Law of the Sea. Project Period: 02/03/2017 to 01/03/2018. The views expressed here are independent of the above-mentioned institutions and belong solely to the authors.

** Professor at the University of Malaya, Malaysia. LL.B (U. Bangalore), LL.M. (LSE), Ph.D. (Sydney). ORCID: http:// orcid.org/0000-0003-1233-0835. The authors may be contacted at: maryg@um.edu.my/Address: Faculty of Law, University of Malaya, 50603 Kuala Lumpur, Malaysia.

*** Advocate and Solicitor of the High Court of Malaya, Malaysia. M.Ec (Malaya), B.Ec/LL.B. (Sydney). ORCID: http:// orcid.org/0000-0002-3686-6821. The authors may be contacted at: anneliz@gmail.com/Address: Faculty of Law, University of Malaya, 50603 Kuala Lumpur, Malaysia.

All the websites cited in this paper were last visited on November 10, 2021. 


\section{Keywords}

South China Sea Disputes, Ex-parte Hearings under Annex VIII, Mandatory Conciliation, A Partnership in Comity and Conciliation, UNCLOS

\section{Introduction: Geopolitical Review of the South China Sea}

The South China Sea, ${ }^{1}$ a semi-enclosed sea under Article 122 of the United Nations Convention on the Law of the Sea 1982 (UNCLOS), ${ }^{2}$ is vital for trade and transport. It is bordered by the Member States of the Association of Southeast Asian Nations (ASEAN) and the People's Republic of China (together called the SCS States).

Figure 1: Spratly Islands in the South China Sea ${ }^{3}$

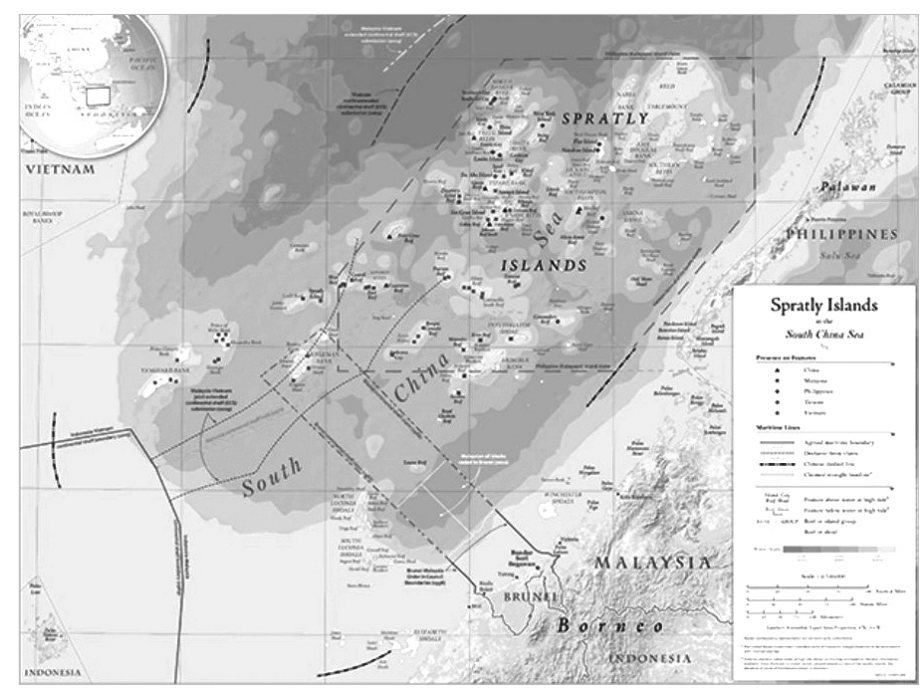

The regional geopolitik ${ }^{4}$ of the South China Sea focuses on historical claims,

1 Located between the Straits of Malacca and Singapore and the Pacific Ocean, Library of Congress, https://www. loc.gov/item/2016587286.

2 Signed in Montego Bay, Dec. 10, 1982. EIF Nov. 16, 1994, in accordance with Article 308(1), 1833 U.N.T.S. 3.

3 Library of Congress: Map, https://www.loc.gov/resource/g9237s.2016587286.

4 Ankit Panda, China Threatens Response if Japan Ramps up South China Sea Activities, Global Conflict Tracker, 
overlapping maritime zone entitlements, resource rights, boundary delimitation, military tensions, and presence of various major maritime powers and allies principally operating under defence treaties. ${ }^{5}$ The contested islands and maritime features are, among others, the Paracel and Spratly Islands, and the Scarborough Shoal. ${ }^{6}$ China and Taiwan have the same claims based on a nine-dash line. ${ }^{7}$ China and Vietnam contest the Paracel Islands. The Spratly Islands comprising more than 700 reefs, islets, atolls and islands are claimed by China, Vietnam, Taiwan, Malaysia, Brunei and the Philippines. Malaysia and Brunei claim the islands as part of their exclusive economic zones (EEZ). ${ }^{8}$

The Scarborough Shoal, a 60-square mile chain of rocks and reefs, is claimed by both China and the Philippines, where the latter's claim is based on geographical proximity and history dating back hundreds of years. ${ }^{9}$ China's man-made floating and submerged reefs on Fiery Cross, Spratlies, has airstrips and missile defence systems. ${ }^{10}$ Regional tensions exist between China, the Philippines ${ }^{11}$ and Vietnam. ${ }^{12}$ China conducts naval manoeuvres and exercises ${ }^{13}$ and has constructed military and industrial outposts on artificial islands. ${ }^{14}$ The US has conducted freedom of navigation exercises in order to secure the sea lines of communication to counter China's

Diplomat, Sept. 30, 2016, https://thediplomat.com/2016/09/china-defense-ministry-military-will-not-sit-idle-ifjapan-expands-involvement-in-south-china-sea. See also A. Erikson et al., The South China Sea's Third Force: Understanding and Countering China's Maritime Militia (Rayburn House Office Meeting, Sept. 21, 2016), https:// docs.house.gov/meetings/AS/AS28/20160921/105309/HHRG-114-AS28-Wstate-EricksonPhDA-20160921.pdf.

5 For example, the Mutual Defense Treaty, signed at Washington Aug. 30, 1951, EIF Aug. 27, 1952, 177 U.N.T.S. 133. See United States Department of State, Treaties in Force: A List of Treaties and Other International Agreements of the United States in Force on January 1, 2020, https:/www.state.gov/wp-content/uploads/2020/08/TIF-2020-Full-website-view.pdf.

6 Other contested maritime features are: Gaven Reef (North), McKennan Reef, Johnson Reef, Cuarteron Reef and Fiery Cross Reef, Subi Reef, Gaven Reef(South), Hughes Reef, Mischief Reef and Second Thomas Shoal.

7 Zhiguo Gao \& Bing Bing Jia, The Nine-Dash Line in the South China Sea: History, Status, and Implications, 107(1) Aм. J. INT'L L. 98-123 (2013).

8 The South China Sea dispute explained, TRT WORLD, Mar. 27, 2017, https://www.trtworld.com/asia/the-southchina-sea-dispute-explained-5963.

$9 \quad$ Id.

10 Id.

11 V. Zhang, Tensions between China and the Philippines Escalate in the South China Sea, CARAvel, May 8, 2021, https:// www.thecaravelgu.com/blog/2021/5/8/tensions-between-china-and-the-philippines-escalate-in-the-south-china-sea.

12 J. Pearson \& H. Gloystein, Vietnam halts South China Sea oil drilling project under pressure from Beijing, REUTERS, Mar. 23, 2018, https://www.reuters.com/article/us-southchinasea-vietnam/vietnam-halts-south-china-sea-oildrillingproject-under-pressure-from-beijing-idUSKBN1GZ0JN.

13 K. Vu et al., Vietnam asks China to withdraw military equipment from South China Sea, ReuTers, May 8, 2018, https:// www.reuters.com/article/us-southchinasea-china-missiles/vietnam-asks-china-to-withdraw-military-equipment-fromsouth-china-sea-idUSKBN1I922M.

14 B. Feleke, China tests bombers on South China Sea island, CNN, May 21, 2018, https://edition.cnn.com/2018/05/20/ asia/south-china-sea-bombers-islands-intl/index.html. 
threats. ${ }^{15}$ The US's military activity and naval presence are meant to support its Southeast Asian partners. ${ }^{16}$ These operations have had some deterrent effect, but led to Sino-US tensions in this maritime area. ${ }^{17}$ These disputes have not been successfully resolved $^{18}$ even through a diplomatic measure under the ASEAN auspices. ${ }^{19}$

The South China Sea Arbitral Award Case 2016-2019 draws attention to the fact that the ex-parte arbitration provisions of Annex VII of the UNCLOS are a violation of the audi alteram partem rule of natural justice. Consequently, the South China Sea States should in their best interests of facing multilateral geo-political tensions, conflicts and relationships comply with mandatory conciliation as a pre-requisite to dispute settlement. In this paper, the authors will try to find a way for partnership in comity and conciliation for the South China Sea Disputes. This paper is composed of seven parts including Introduction and Conclusion. It will discuss Annex VII Arbitration: Inter-State, Non-consensual and Ex-parte; Mandatory Conciliation: A proposal for the Settlement of the South China Sea Disputes; and Scope of the Proposed Conciliation Mechanism for the South China Sea Disputes.

\section{Review of the South China Sea Arbitral Award Case}

The South China Sea Arbitral Award Case (Philippines v. PRC) (hereinafter SCS Case) emerged from this crucible of tensions and conflicts, ${ }^{20}$ where the Philippines sued

15 L. Shen, US defence chief Jim Mattis'visit unlikely to ease tensions over South China Sea and Taiwan: Chinese analysts don't expect talks in Beijing to ease tensions, S. CHInA Morning Post, June 26, 2018, https://www.scmp. com/news/china/diplomacy-defence/article/2152626/us-defence-chief-jim-mattis-arrives-china-open-dialogue; U.S. destroyer challenges China's claims in South China Sea, Reuters, Aug. 10, 2017, https://www.reuters.com/article/ususa-china-southchinasea-exclusive-idUSKBN1AQ0YK.

16 Id.

17 China hacking U.S. firms linked to dispute in South China Sea: FireEye, JAPAN Times, Mar. 16, 2018, https:// www.japantimes.co.jp/?post type=news\&p=1376260\#.WqvAjvnwa70; C. Buckley, Chinese Navy Returns Seized Underwater Drone to U.S., N. Y. Trmes, Dec. 20, 2016, https://www.nytimes.com/2016/12/20/world/asia/chinareturns-us-drone.html?hp\&action=click\&pgtype=Homepage \&clickSource=story-heading \&module=first-columnregion\&reg;ion=top-news\&WT.nav=top-news.

18 J. Bautista, Track 2 diplomacy in aid of official dialogue on South China Sea, Manila Times, Jan. 21, 2017, https:// www.manilatimes.net/track-2-diplomacy-aid-official-dialogue-south-china-sea/308028.

19 ASEAN Declaration on the Conduct of Parties in South China Sea (Nov. 4, 2002), ๆ 4. See C. Hill, China Boasts of Strategy to 'Recover' Islands Occupied by Philippines, China News, May 28, 2013, https://chinanews.net. au/2013/05/28/china-boasts-of-strategy-to-recover-islands-occupied-by-philippines; Memorial of Philippines, South China Sea Arbitration (Phil. v. P.R.C.), PCA Case Repository No. 2013-19 (vol. X), annex 325.

20 South China Sea Arbitration (Phil. v. P.R.C.), Award, PCA Case Repository No. 2013-19, (July 12, 2016), at 1, https://pcacases.com/web/sendAttach/2086. (Award of 2016) 
China for infringing its legal rights and ascertaining the lawfulness of China's actions in the South China Sea, at the Permanent Court of Arbitration (PCA), The Hague, under the UNCLOS, an action China resisted. ${ }^{21}$

After the Tribunal decided in its 2015 Award on Jurisdiction and Admissibility that it had jurisdiction to consider certain of the Philippines' Submissions, it proceeded to the Merits phase. ${ }^{22}$ In 2016, the Tribunal found against China. The authors submit that upon a closer examination of the SCS Case, two points come to the fore: first, ex=parte hearings under Annex VII provisions violate the principle of natural justice; and secondly, the claimant States Parties did not engage in voluntary or mandatory conciliation before resorting to an Annex VII Arbitration under the UNCLOS. ${ }^{23}$ China's Declaration under Part XVII of the UNCLOS that ousted the dispute settlement procedures of the UNCLOS was considered irrelevant. ${ }^{24}$

The Philippines instituted the Annex VII Arbitration ${ }^{25}$ as it considered judicial intervention was necessary for the bilateral diplomatic efforts, yielded no positive outcome. ${ }^{26}$ Philippines' counsel, P.S. Reichler was mindful of China’s “salami-

21 Michael Sheng-ti Gau, The 2015 Award on Jurisdiction and Admissibility of the South China Sea Arbitration and the Insurmountable Thresholds, in Chinese (Taiwan) Yearbook of International LaW \& Affairs 62-108 (Ying-jeou Ma ed., 2015).

22 In Matter of Arb. (Phil. v. P.R.C.), Award on Jurisdiction \& Admissibility, PCA Case Repository No. 2013-19 (Oct. 29, 2015), https://pcacases.com/web/sendAttach/2579. The Tribunal decided that Article 283 had been satisfied. (Award on Jurisdiction 2015.)

23 For overall responses of the Chinese Society of International Law, see Chinese Society of International Law, The South China Sea Arbitration Awards: A Critical Study, (17) CHINESE J. of INT'L L. 207-748 (2018), https://academic.oup.com/ chinesejil/article/17/2/207/4995682.

24 China "does not accept any of the procedures provided for in Section 2 of Part XV of the Convention with respect to all the categories of disputes referred to in paragraph 1 (a), (b) and (c) of Article 298 of the Convention." See China upon ratification (June 7, 1996) and Declaration made after ratification (Aug. 25, 2006), United Nations Division for Ocean Affairs and the Law of the Sea (UNDOALOS), Settlement of Disputes Mechanisms, http://www.un.org/ depts/los/convention_agreements/convention_declarations.htm\#China\%20after\%20ratification; China refuses to accept the court's authority, Global Conflict Tracker, https://www.cfr.org/interactives/global-conflict-tracker?_utm source=1-2-2\#!/conflict/territorial-disputes-in-the-south-china-sea.

25 Supra note 20.

26 See Arbitration under Annex VII of the United Nations Convention on the Law of the Sea, Republic of the Philippines v. People's Republic of China, Memorial of the Philippines, Vol. III, Annexes, Annex 26, for Government of Philippines, Department of Foreign Affairs, Release 69, RP, PRC to Convene Working Group for Talks on South China Sea, at 2 (Mar. 30, 2014), https://files.pca-cpa.org/pcadocs/The\%20Philippines\%27\%20Memorial\%20-\%20 Volume\%20III\%20\%28Annexes\%201-60\%29.pdf; Arbitration under Annex VII of the United Nations Convention on the Law of the Sea, Republic of the Philippines v. People's Republic of China, Memorial of the Philippines (vol. VI), annex 183, for Government of the Republic of the Philippines and Government of the People's Republic of China, Joint Press Communiqué: Philippines-China Foreign Ministry Consultations (July 29-31 July, 1998), at 1-3 (Mar. 30, 2014), https://files.pca-cpa.org/pcadocs/The\%20Philippines\%27\%20Memorial\%20-\%20Volume\%20VI\%20 \%28Annexes\%20158-221\%29.pdf. 
slicing/cabbage strategy." ${ }^{27}$ Cabbage strategy refers to the little steps taken over time to consolidate China's de facto control throughout the South China Sea, where one layer is peeled off at a time. However, when done individually, it is not enough to provoke a crisis. China resisted jurisdiction through its notes verbales to the PCA in August 2013. ${ }^{28}$ In support of its claims, the Philippines submitted several bilateral diplomatic communications as evidence of exhaustion of negotiations under Article 283 of the UNCLOS, ${ }^{29}$ preferring multilateral negotiations instead of bilateral talks as proposed by China. The Tribunal held that even independently of Article 283, the Philippines was not obliged to pursue negotiations before resorting to arbitration as it had negotiated with China. In this regard, the Tribunal also maintained that international law did not require a State to continue negotiations when the possibility of a negotiated solution had been exhausted, as seen in Paragraph 350 of its own Award on Jurisdiction 2015. ${ }^{30}$

In the instant SCS Case, China did not torpedo the arbitration proceedings by a subsequent withdrawal but voiced ab initio disagreement. Though case management is essential for every dispute, China did not participate in the procedural calendar of the arbitration proceedings. The Tribunal following the UNCLOS's rules confirmed that China, despite its objection and non-appearance, was a party to the arbitration, with ensuing rights and obligations, stating that it would be bound under international law by any decision of the Tribunal. ${ }^{31}$ With China's absence, the Tribunal safeguarded Philippines' procedural rights following the Arctic Sunrise Case $^{32}$ and averted three disadvantages: ${ }^{33}(1)$ delay; (2) inability to address specific issues and "having to guess" China's arguments; ${ }^{34}$ and (3) to be able to "formulate arguments for both States.",35

27 See Philippines' written submissions by A.F. Del Rosario, Secretary of Foreign Affairs, at 22, Final Transcript Day 1-Jurisdiction Hearing, https://pcacases.com/web/sendAttach/1399; P. Reichler's arguments, Final Transcript Day 1-Jurisdiction Hearing, at 29, https://pca-cpa.org/en/cases/7.

28 PRC Ministry of Foreign Affairs, Position Paper of the Government of the People's Republic of China on the Matter of Jurisdiction in the South China Sea Arbitration Initiated by the Republic of the Philippines (Dec. 7, 2014). Four separate letters sent to members of the Arbitral Tribunal, see id. Day 1-Hearing on Jurisdiction and Admissibility.

29 Reichler, supra note, at 27.

30 See also Award of 2016, supra note 20, IV.B. Summary of the Tribunal's Award on Jurisdiction, at 60-2, 9 159 $\& 160$.

31 Award on Jurisdiction 2015, supra note 22, at $\uparrow 118$, recited from Military and Paramilitary Activities (Nicar. v. U.S.), Judgment, 1986 I.C.J. 14, 28 (June 27, 1986); Arctic Sunrise Arbitration (Neth. v. Russ.), Award on Jurisdiction, PCA case Repository No. 2014-02, \60 (Perm. Ct. Arb., Nov. 26, 2014), https://pcacases.com/web/sendAttach/1325.

32 Arctic Sunrise (Neth. v. Russ.), Provisional Measures, 2013 ITLOS Rep. No. 22, 56 (Nov. 2013), https://www. itlos.org/fileadmin/itlos/documents/cases/case_no.22/published/C22_Order_221113.pdf.

33 Letter from the Philippines to the Tribunal (July 31, 2013) (commenting on draft Rules of Procedure), $\uparrow \uparrow$ 123-124.

34 Award of 2016, supra note 20, at $\$$ 124-25, for reference to Article 25(2) of the Rules of Procedure.

35 Award on Jurisdiction 2015, supra note 22, at 119. 
Independent of Annex VII, the Tribunal discerned China's position from its communications and statements ${ }^{36}$ by equating this practice to that of international courts and tribunals. ${ }^{37}$ China indirectly assisted the Tribunal: first, when it published its Position Paper in December 2014; second, when it addressed six letters from the former and successor Chinese Ambassadors to the Tribunal (paragraph 127); and third when it held frequent press briefings of the Chinese Ministry of Foreign Affairs that spoke on issues before the Tribunal (paragraph 127). To ensure procedural fairness, the Tribunal explained the role and function of Article 9 (paragraph 119) ${ }^{38}$ and of Article 5 of Annex VII to both Parties. ${ }^{39}$ To protect China's rights, the Tribunal:

1. ensured the Registry staff conveyed written communications from the Chinese Embassy to the Tribunal;

2. bifurcated the proceedings between jurisdiction and merits; ${ }^{41}$

3. to facilitate China's participation, de facto if not de jure, encouraged China to attend the proceedings; ${ }^{42}$

4. held that it would consider possible issues of jurisdiction and admissibility even if they were not addressed in China's Position Paper; ${ }^{43}$

5. stated the principles of impartiality and independence that it meant to observe; ${ }^{44}$ and

6. ensured that China was updated on all developments in the arbitration and could participate in the proceedings at any stage. ${ }^{45}$

Unlike consensual arbitration, ${ }^{46}$ except for two matters, ${ }^{47}$ the Tribunal considered and admitted almost all the matters raised in the Philippines' submissions, and said that, “...under Article 5 of Annex VII to the Convention it was under a duty to "assur[e] [to] each party a full opportunity to be heard and to present its case."”48 The Philippines

36 Id. at 68.

37 Procedural Order No. 4, at 5 (Apr. 21, 2015). For details, see Artic Sunrise case, supra note 32, at 54.

38 Award on Jurisdiction 2015, supra note 22, at 119.

39 Id. For details, see Rules of Procedure, art. 10(1), ๆ 69.

40 Award on Jurisdiction 2015, supra note 22, ๆฯ 56, 117 \& 121.

41 Id. at $91159,160 \& 391$.

42 The Arbitral Tribunal comprised Judge Thomas A. Mensah (Presiding Arbitrator), Judge Jean-Pierre Cot, Judge Stanislaw Pawlak, Professor Alfred H.A. Soons \& Judge Rüdiger Wolfrum.

43 Award on Jurisdiction 2015, supra note 22 , at $\uparrow 15$.

44 Id. at 935 .

45 Id. at 18.

46 Land Reclamation by Singapore in and around Straits of Johor (Malay. v. Sing.), Award on Agreed Terms, 27 R.I.A.A. 133, 144 ๆ D (Perm. Ct. Arb., Sept. 1, 2005), https://legal.un.org/riaa/cases/vol_XXVII/133-145.pdf.

47 For the Philippines pleadings on the six grounds, see Reichler supra note 27.

48 Id. 
contested China's maritime entitlements of certain maritime features ${ }^{49}$ and alleged that China breached several provisions, for example, Articles 60, 80, 94, 123, 192 and 194(1) and (5); and 206 and Rules 2, 6, 7, 8, 15, and 16 of the International Convention for the Prevention of Collisions at Sea 1972 in the vicinity of Scarborough Shoal.

The Tribunal found that the questioned maritime features did not generate an EEZ or continental shelf and that they fell within the Philippines claim. The Tribunal also found that China caused irreparable harm to the coral reef ecosystem through its breach of Articles 192 and 194(5) of the UNCLOS, by harvesting endangered species and giant clams ${ }^{50}$ and Articles 123, 192, 194(1), 194(5) and 206 by land reclamation and construction of artificial islands, installations, and structures at various maritime features. China was required to desist from such wrongdoings, ${ }^{51}$ absent a standing international machinery to ensure compliance. ${ }^{52}$ The SCS Case has highlighted the omissions of the UNCLOS's Annex VII ex-parte hearings to ensure compliance with the principle of natural justice and the role and future of mandatory conciliation under the UNCLOS. These two omissions and a solution in the context of the South China Sea are considered here.

\section{Annex VII Arbitration: Inter-State, Non-consensual and Ex-parte}

The SCS Case is characterized by the PCA as an inter-State arbitration. In this paper, the lack of China's agreement to the arbitration is described as "non-consensual" and China's absence in the arbitration proceedings is referred to as "ex-parte arbitration." The Annex VII procedure may be used for inter-State, inter=partes and ex-parte arbitration proceedings. Article 13 of Annex VII states: "The provisions of this Annex shall apply mutatis mitandis to any dispute involving entities other than State Parties." Inter-State inter-partes hearings under Annex VII may be said to be protected by the rules of natural justice set out in Article 11 of this Annex. Article 11 provides for an appellate procedure should the States Parties so desire. "The award shall be final and without appeal, unless the parties to the dispute have agreed to advance 
to an appellate procedure. It shall be complied with by the parties to the dispute." However, inter-State ex-parte, non-consensual arbitrations under Annex VII violate the audi alteram partem rule of natural justice with dire implications for procedural fairness being varied from Tribunal to Tribunal and res judicata implications for the non-participating State in international law. This point is examined below, while the jus dicere ${ }^{53}$ of the Tribunal is not examined. Reichler, counsel for the Philippines, summed it up before the Tribunal as follows:

It is our duty, especially in a case of this significance where only one party is present, to extend to you our fullest cooperation, and to facilitate the performance of your task as best we can, by furnishing you with clear evidence of the parties' conflicting claims, direct responses to the challenges to your jurisdiction that China has raised, or might have raised; and answers to your questions that are as complete and helpful as possible. We hope you feel that we have lived up to our responsibilities thus far, in our written pleadings. We give you our unequivocal commitment to do so during these oral hearings as well. ${ }^{54}$

Under the rules of natural justice, the two constituents of a fair hearing are the rule against bias, that is, nemo iudex in causa sua, or "no man [shall be] a judge in his own cause"; and the right to a fair hearing, audi alteram partem, or "hear the other side.",55 The Annex VII Arbitration of the UNCLOS in ex-parte hearings runs foul of the second rule-"hear the other side."

When inter-State, ex-parte non-consensual arbitrations have final and binding awards that are not appealable, they are considered systemic weaknesses of the Annex VII Arbitration procedure. The weaknesses are a violation of the rule of natural justice-audi alteram partem -which requires both States to be heard. The term 'ex-parte' does not appear in Annex VII of the UNCLOS. ${ }^{56}$ The Convention does not prohibit the establishment of tribunals that conduct inter-State, non-consensual exparte arbitrations with final and binding awards that are not appealable. Such exparte arbitrations without the fair hearing rule are not only found in Annex VII, but also in Annex VIII. Article 9 of Annex VII states that the Award binds the absent State, provided the Tribunal had satisfied itself that it had jurisdiction over the

53 Id. at 64.

54 Reichler, supra note 27, at 29.

55 Rosenne, supra note 52, at 65.

56 N. Blackaby et al., Redfern and Hunter on International Arbitration 46 \& 51 (6th ed. 2015). See also J. Lew et al., Comparative International Commercial Arbitration 35 \& 50 (2003); E. Gaillard \& J. Savage (eds.), Fouchard Gaillard Goldman on International Commercial Arbitration 11-2 (1999). 
dispute and that the claim was well-founded in fact and law. Article 10 of Annex VII states that the list of claims founded in fact and law, constitutes the list of "Agreed Disputes." The list must be affirmed by both States as the Award shall be confined to the subject matter of the dispute and will state the reasons on which it is based. The implementation of Article 12 of Annex VII on the "Interpretation or implementation of the award" is also unclear for Annex VII ex-parte hearings. Article 4 of Annex VIII states: "Annex VII, Articles 4 to 13, apply mutatis mutandis to the special arbitration proceedings in accordance with this Annex."

Municipal common law jurisdictions, such as, for example, in Malaysia, use exparte rules in the grant of ex-parte interim injunctions. These injunctions are granted in urgent cases and valid for twenty-one days only as upheld in case law and Order 29 Rule 1(2B) of the Rules of Court 2012. ${ }^{57}$ They include interim injunctions such as the Mareva Injunction, the Anton Piller Order, Ad Interim Injunction, Quia Timet Injunction, the Erinford Injunction and the Fortuna Injunction. The temporariness and appealable nature of the ex-parte interim injunction rule in common law jurisdictions is in direct contrast to the permanent and final nature of the ex-parte arbitration rule in Annex VII of the UNCLOS. Consequences for States are, therefore, dire in the latter.

The Annex VII ex-parte arbitration rule lacks the common law jurisdictional feature of being a mere "temporary measure before a full trial." It is submitted that a non-consensual, ex-parte arbitration may be considered as unlawful and lacking in goodwill where, for example, any of the four tests below, read disjunctively, are answered in the affirmative:

1. Did the Tribunal invite participation of the State against its consent on jurisdiction and on merits or list of agreed disputes?;

2. Has there been an aggravation of the dispute?;

3. Are the States Parties' interests compr omised?; or

4. Are third States interests compromised?

Where the award is to be final and binding, then the proceeding should be interpartes and consensual. The Model Submission Agreement of the Asian International Arbitration Centre focuses on consent of Parties in submitting the dispute to arbitration. $^{58}$

57 RIH Services (M) Sdn Bhd $v$. Tanjung Tuan Hotel Sdn Bhd [2002] 3 CLJ 83 (Court of Appeal) per Abdul Hamid Mohamad JCA.

58 The Asian International Arbitration Centre (formerly known as the Kuala Lumpur Regional Centre for Arbitration, Arbitration Rules, https://www.aiac.world/wp-content/arbitration/Arbitration-Rules-2018.pdf. 


\section{Mandatory Conciliation: A Proposal for the South China Sea Dispute Settlement}

In the SCS Case, the States parties did not enter into voluntary or mandatory conciliation before the commencement of the Annex VII Arbitration, even though the UNCLOS provides for conciliation, voluntary and mandatory, in several provisions as discussed here. Where diplomacy or bilateral or multilateral negotiations fail to outwork a peaceful solution of the disputes, States should embark on conciliation. Several references to conciliation are provided for in the General Act of Arbitration 1928 (Pacific Settlement of International Disputes, that provided for conciliation in 16 Articles), the UN Charter, the Regulations on the Procedure of International Conciliation adopted by the Institute of International Conciliation (hereinafter 1961 Convention), and the UNCLOS. The Tribunal in the SCS Case did not explain the conciliation procedure and why it was not necessary for the States Parties to have used it.

However, the Timor Leste-Australia Conciliation Commission offered some explanations on the importance of conciliation. Based on the above examination of the conciliation provisions, it would appear that conciliation has always been accepted as a quasi-legal or legal/judicial procedure founded on the principles of natural justice, including the audi alteram partem rule in various conventions adopted before and after World War II. Conciliation, an inter-State negotiating tool, is referred to in pre-and post-UN Charter agreements. ${ }^{59}$ Under the UNCLOS, the conciliation provisions fall potentially within the compulsory jurisdiction of international tribunals (Articles 279299 and Annexes VII-VIII), as highlighted below. ${ }^{60}$

\section{A. Pre-UN Charter}

Jean-Pierre Cot defines international conciliation as "intervention in the settlement of an international dispute by a body having no political authority of its own but enjoying the confidence of the parties to the dispute and entrusted with the task of investigating

59 See, e.g., VCLT 1969 art. 66; Convention on Biological Diversity 1992, art. 27, annex 2-pt. 2; and UN Framework Convention on Climate Change 1992, art. 14. For details, see A. Reinisch, Elements of Conciliation in Dispute Settlement Procedures relating to International Economic Law, in Conciliation IN InTERnational Law, The OSCE Court of Conciliation and Arbitration 116-32 (C. Tomuschat et al. eds., 2016); B. Peter, International Commercial Arbitration and Conciliation in UNCitral qף 10-001-007 (2010); S. Veitch (ed.), Law and the Politics of Reconciliation 87 (2007).

60 For details on environmental dispute settlement, see A. Boyle, Environmental Dispute Settlement, in Max Planck EnCyClopedia of Public International Law, https:/opil.ouplaw.com/view/10.1093/law:epil/9780199231690/law9780199231690-e1949?prd=OPIL. 
every aspect of the dispute and of proposing a solution which is not binding on the parties." ${ }^{\circ 1}$ Cot urged us to examine the true significance of the institution, its possibilities and limitations that is offering conciliation services. He states that there are differences between conciliation, mediation and established commissions of inquiry and other forms of dispute settlement, as some commissions examine facts and others could well act as arbitral bodies. ${ }^{62}$ Mediation was not conciliation, though it was based on the principle of mediation. Conciliation was somewhere in between the learned "Wise Man and the Prince" who represented the State.

The 1899 Convention for the Pacific Settlement of International Disputes provided in Article 5 that the functions of the mediator ceased when either of the parties to the dispute, or the mediator himself declared that the means of reconciliation proposed by him were not accepted. ${ }^{63}$ Article 9 of Title III of the 1899 Convention also provided for an International Commission of Inquiry for settling differences of opinion for points of facts.

In differences of an international nature involving neither honor nor vital interests, and arising from a difference of opinion on points of fact, the Signatory Powers recommend that the parties, who have not been able to come to an agreement by means of diplomacy, should as far as circumstances allow, institute an International Commission of Inquiry, to facilitate a solution of these differences by elucidating the facts by means of an impartial and conscientious investigation.

Article 10 of Title III dealt with the constitution of the International Commissions of Inquiry by special agreement. The 1899 Convention mandated that for an inquiry, it was necessary that the facts were examined, and the extent of the Commissioners' powers, determined. It then settled the procedure. On the inquiry, both sides were to be heard. Various details, such as the form and the periods to be observed, were to be stated in the inquiry Convention or decided by the Commission itself. Article 11 (Title III) stated that the International Commissions of Inquiry were to be formed according to the 1899 Convention. Under Article 12 (Title III), the disputing States were to supply the International Commission of Inquiry with all means and facilities necessary to enable it to be completely acquainted with and to accurately understand the facts in question. Article 13 (Title III) required the International Commission of Inquiry to communicate its Report to the conflicting Powers, signed by all the members of the

61 J. Cot, International Conciliation 9 (1972).

$62 I d$. at $5 \& 12$.

63 See Pacific Settlement of International Disputes (The Hague I), Treaties and Other International Agreements of the United States of America 1776-1949 (July 29, 1899), at 230-46, https://tile.loc.gov/storage-services/service/1//ltreaties// 1ltreaties-ustbv001/11treaties-ustbv001.pdf. 
Commission. The terms of Article 14 (Title III) stated that the report of the International Commission of Inquiry was limited to a statement of facts and was not an Arbitral Award. The disputing States had the freedom to interpret this statement.

Article 5 of the 1907 Convention for the Pacific Settlement of Disputes repeats Article 5 of the 1899 Convention. Articles 9 to 36 of the 1907 Convention provided for the establishment of International Commissions of Inquiry. ${ }^{64}$ Article 10 states that the International Commissions of Inquiry were to be constituted by special agreement between the Parties in dispute to examine the defined facts and determine the mode and time in which the Commission was to be formed and the extent of the powers of the Commissioners. The situs, authorized language of the Commission, and terms and conditions of the States Parties, were considered. Where the States felt it was necessary to appoint Assessors, the 1907 Convention of Inquiry was able to determine the mode of their selection and the extent of their powers. Where the Inquiry Convention had not the situs, Article 11 provided that it was to sit at The Hague. The place of meeting, once fixed, was not to be altered by the Commission except with the assent of the Parties. Likewise, if the language was not determined, the Commission was able to determine the language.

The General Act of Arbitration 1928 provided for conciliation in 16 Articles. ${ }^{65}$ Chapter I (Conciliation) provided in Article 1 that: "Disputes of every kind between two or more Parties to the present General Act ... shall, ... , be submitted, ... , to the procedure of conciliation." Article 2 stated that the disputes referred to in the preceding Article were to be submitted to a permanent or special Conciliation Commission constituted by the Parties to the dispute. Article 3 provided that on a request to that effect being made by one of the Contracting Parties to another Party, a permanent Conciliation Commission was to be constituted within a period of six months.

Conciliation was also used after World War $\mathrm{II}^{66}$ where it was operationalized through the mandate of the Conciliation Commission. ${ }^{67}$ More formalized and yet the same in essence than the Cot's definition, Article 1, Section 1 of the 1961 Convention on the Procedure of International Conciliation defined "conciliation" as:

For the purpose of the present provisions, "conciliation" means a method for the settlement of international disputes of any nature according to which a Commission

64 The Hague Convention for the Pacific Settlement of International Disputes 1907, https://docs.pca-cpa.org/2016/ 01/1907-Convention-for-the-Pacific-Settlement-of-International-Disputes.pdf.

6593 L.N.T.S. 344-363 (Sept. 26, 1928), https://treaties.un.org/doc/Publication/UNTS/LON/Volume\%2093/v93.pdf.

66 Un Secretariat, Systematic Survey of Treaties for the Pacific Settlement of International Disputes 19281948, https://lawcat.berkeley.edu/record/353054? ln=en.

67 S. Koopmans, Diplomatic Dispute Settlement-The Use of Inter-State Conciliation 90-1 (2008). 
set up by the Parties, either on a permanent basis or on an ad hoc basis to deal with a dispute, proceeds to the impartial examination of the dispute and attempts to define the terms of a settlement susceptible of being accepted by them, or of affording the Parties, with a view to its settlement, such aid as they may have requested. ${ }^{68}$

A Conciliation Commission for the settlement of World War II issues was attributed to some arbitrations or treaties in the past. ${ }^{69}$ Articles 33, 36(1) and 36(3) of the UN Charter provide for the peaceful settlement of disputes including conciliation, ${ }^{70}$ but details on time limits for a legal claim are not addressed. ${ }^{71}$ The ICJ has also stressed on the importance of negotiations in dispute settlement. ${ }^{72}$

\section{B. The UNCLOS}

The Preamble to the UNCLOS states: "Prompted by the desire to settle, in a spirit of mutual understanding and cooperation, all issues relating to the law of the sea ..." Part XV of the UNCLOS encompasses three sections on dispute settlement that considers Optional, Mandatory and Annex V Conciliation. Section 1 (General Provisions) promotes optional conciliation designed to prevent the aggravation of a dispute. Section 1 does not state how many times the States Parties should meet in consultations and negotiations before an Annex VII Arbitration can start, while it does state that the States Parties are invited to submit their dispute to conciliation. In this section, Article 281 refers to a procedure where no settlement has been

68 International Conciliation, Institut De Droit International: Session of Salzburg (1961), https://www.idi-iil.org/app/ uploads/2017/06/1961_salz_02_en.pdf.

69 See, e.g., Jay Treaty 1794; Alabama Claims Arbitration 1872; Treaty of Washington 1872. For details, see H. Mosler, Problems and Tasks of International Judicial and Arbitral Settlement of Disputes Fifty Years after the Founding of the World Court, in Proc. Max Planck Institute of Comparative Public Law and International Law's Judicial Settlement of International Disputes, International Court of Justice, Other Courts and Tribunals, Arbitration and Conciliation: An International Symposium 3-15 (1974); Hans von Mangoldt, Arbitration and Conciliation, in id. at 417-552; C.Tomuschat et al. (eds.), Conciliation in International Law: The OSCE Court of Conciliation and Arbitration (2016); C. Tomuschat Conciliation within the Framework of the OSCE Court of Conciliation and Arbitration: An Assessment from the Viewpoint of Legal Policy, in International Commercial Arbitration and CONCILIATION IN UNCITRAL 94-104 (P. Binder ed., 2009).

70 The. UN Charter does not mention "good offices." For mediation and good offices, see Beagle Channel Arbitration (Argentina v. Chile), Judgment, 52 I.L.R. 93 (1977). See also Gabčíkovo-Nagymaros (Hung. v. Slovk.), Judgement 1997 I.C.J. Rep. 7 (Sept. 25); U.N. Doc. S/RES/36 (1947), https://digitallibrary.un.org/record/111985?ln=en; U.N. Doc. S/RES/35 (1947), https://digitallibrary.un.org/record/111984?ln=en.

71 For time limits of a legal claim in conciliation, see N. Gallus, The Temporal Jurisdiction of International Tribunals 2-3 \& 39-40 (2017).

72 Application of the International Convention on the Elimination of All Forms of Racial Discrimination (Geor. v. Russ.), Judgement, 2011 I.C.J. Rep. 75, ๆ 160 (Apr. 1). 
reached by the parties such as inter-State conciliation. ${ }^{73}$ Annex $\mathrm{V}$, Section 1 is titled "Conciliation Procedure Pursuant to Section 1 of Part XV." Optional Conciliation in Annex V, Section 1 comprises ten Articles.

Part XV, Section 2 refers to Compulsory Procedures Entailing Binding Decisions comprising Articles 286 to $296 .^{74}$ Section 3 (Articles 297-299) deals with Limitations and Exceptions to Applicability of Section $2 .{ }^{75}$ Compulsory conciliation in Annex V, Section 2 is titled "Compulsory Submission to Conciliation Procedure Pursuant to Section 3 of Part XV." The rules of Annex V conciliation are similar to Annex VII's arbitration rules.

\section{Optional Conciliation: Articles 284 and 285}

Article 284 invites States to conciliate their disputes and to use Annex V procedures. This Article provides that both States may agree to conciliation by accepting the invitation to conciliate and the procedure for conciliation. Article 285 provides that Part XI disputes are to be settled under Part XV. This Section applies mutatis mutandis to Parties and entities other than States Parties.

\section{Mandatory Conciliation: Article 297}

Section 3 clarifies the scope of Section 2 as Section 3 states that Section 2 is subject to limitations and exceptions in Article 297. Section 2 deals with compulsory procedures entailing binding decisions. ${ }^{76}$ Disputes subject to compulsory settlement in Section 2 as provided for in Article 297(1)-(3) are:

- Breach by coastal State of the freedom of navigation, overflight or the laying of submarine cables and pipelines or in regard to other internationally lawful uses of the sea specified in Article 58 (Article 297(1)(a));

- User State infringements of laws and regulations adopted by the coastal State in Article 297(1)(a), Article 297(1)(b);

- Coastal State breach of the marine environment rules (Article 297(1)(c));

- Article 297(2)(a) concerning coastal State discretions and decisions under Articles

73 Timor Sea Conciliation (Timor-Leste v. Austl.), Decision on Australia's Objections to Competence, PCA case Repository No. 2016-10, https://pca-cpa.org/en/cases/132. For Decision on Australia's Objections to Competence, see A Conciliation Commission Constituted under Annex V to the 1982 United Nations Convention on the Law of the Sea, https://pcacases.com/web/sendAttach/10052.

74 UNCLOS arts. $280 \& 281$.

75 J. Crawford, Brownlie's Principles of Public International Law 719 (8th ed. 2012). See also J. Merrills, International Dispute Settlement 58 (5th ed. 2011).

76 For compulsory conciliation, see T. TREves, Compulsory Conciliation in the UN Law of the Sea Convention, in LiBER Amicorum Gunther JaenicKe-Zum 85 (G. Jaenicke et al. eds., 1999). 
246 and 253 on marine scientific research; and

- Article 297(3)(a) concerning coastal State fisheries.

Article 297(2)(b) and (3)(b) refer to compulsory conciliation for marine scientific research and conservation of living resources in the coastal State's EEZ, respectively. Sub-paragraph (3)(b) provides where the disputes in Part XV are not settled by recourse to Section 1 of this part, a dispute shall be submitted to conciliation under Annex $\mathrm{V}$, Section 2 at the request of any party to the dispute.

Article 297(3)(c) provides that the conciliation commission cannot substitute its discretion for that of the coastal State. Article 297(3)(d) provides that the report of the conciliation commission shall be communicated to appropriate international organizations. Article 297(3)(e) mandates opposite or adjacent developed coastal or developing coastal States that negotiate the Access to Surplus Fisheries Agreements, to include a clause on measures that they should take in order to minimize the possibility of a disagreement concerning the interpretation or application of the agreement, and how to proceed if a disagreement arises.

Article 298 is titled "Optional exceptions to applicability of section 2." Article 298(1) allows States and entities to declare that they exclude the application of compulsory binding procedures for dispute settlement in respect of certain specified categories of disputes. Under Article 298(1)(a)(i), States can exclude the application of compulsory binding dispute settlement procedures for sea boundary delimitations and historic bays and titles, but subsequently when a dispute arises, a State having made such a declaration shall, ... , accept submission of the matter to conciliation under Annex V, Section 2.

However, sea boundary disputes that are settled by an arrangement between Parties and any such dispute settled in accordance with a bilateral or multilateral agreement binding upon those parties are to be excluded from conciliation. Article 298(1)(a)(ii) requires States Parties to negotiate an agreement on the basis of the conciliation commission's report. However, if these negotiations do not result in an agreement, then, by mutual consent, they are required to submit the question to one of the procedures provided for in Section 2, unless they otherwise agree. Articles 297 and 298 refer to conciliation which allows States Parties to a dispute to twice resort to conciliation under these Articles.

Article 298(2) allows a State Party to withdraw a declaration under paragraph 1, or to submit a dispute excluded by such declaration to any Convention procedure. Article 298(3) stresses on consent and mandates that "a State Party, ... , can only submit a dispute falling within the excepted category of disputes to any Convention 
procedure against another State Party ...” Further, Article 298(4) allows a State Party that has made a declaration under paragraph 1(a) to settle a dispute that has been submitted by any other State Party against the declarant party to the procedure specified in such declaration. Finally, Article 298(5) and (6) add that a new declaration or withdrawal of a declaration does not affect proceedings before a court or tribunal, unless the Parties otherwise agree. Such declarations and withdrawals shall be deposited with the UN Secretary-General. Article 299 recognises the right of States Parties to agree upon a procedure for excepted disputes under Article 297 or by a declaration, to reach an amicable settlement. The effect of these provisions is to grant States Parties the right to choose the preferred forum for a peaceful settlement of their maritime dispute and to state the scope of excepted disputes.

\section{Table 1: Summary of Conciliation under Part XV of the UNCLOS}

\begin{tabular}{|c|c|}
\hline $\begin{array}{l}\text { Mandatory dispute } \\
\text { settlement under } \\
\text { Sections } 2 \text { and } 3\end{array}$ & $\begin{array}{l}\text { - Disputes concerning the interpretation or application of the } \\
\text { Convention in regard to coastal State sovereign rights or jurisdiction } \\
\text { in the EEZ, namely: } \\
\text { - Discretions in granting marine scientific research decisions (Articles } \\
\text { 297(2), Articles } 246 \text { and 253); } \\
\text { - Breach of conservation and management of living resources of EEZ } \\
\text { (Article } 297 \text { (3)(b)); } \\
\text { - Arbitrary refusal to determine the allowable catch and its capacity } \\
\text { to harvest living resources in fisheries; and } \\
\text { - Arbitrary refusal to allocate declared surplus to any State (Articles } \\
62,69 \text { and } 70 \text { followed by Articles } 297(3)(d) \text { and } 297(3)(e)) \text {. } \\
\text { - Environmental and natural resources disputes. }\end{array}$ \\
\hline $\begin{array}{l}\text { Optional dispute } \\
\text { settlement to } \\
\text { Section } 2\end{array}$ & $\begin{array}{l}\text { - Sea boundary delimitations and disputes involving historic bays } \\
\text { and titles (Article 298(1)(a)(i)); and } \\
\text { - Failure to negotiate an agreement following the conciliation } \\
\text { commission's report (Article 298(1)(a)(ii)). }\end{array}$ \\
\hline $\begin{array}{l}\text { Excluded from } \\
\text { dispute settlement }\end{array}$ & $\begin{array}{l}\text { - Sea boundary disputes that are settled by a bilateral or multilateral } \\
\text { agreement binding upon those Parties are to be excluded (Article } \\
\text { 298(1)(a)(iii)); } \\
\text { - Disputes concerning military and law enforcement activities } \\
\text { (Article 298(1)(b)); and } \\
\text { - United Nations Security Council disputes (Article } 298(1)(c)){ }^{78}\end{array}$ \\
\hline
\end{tabular}

77 Boyle, supra note 60.

78 S. Allen, Article 297 of the United Nations Convention on the Law of the Sea and the Scope of Mandatory Jurisdiction, 48 OCEAN DEV. \& INT'L L. 313-30 (2017), https://www.tandfonline.com/doi/full/10.1080/00908320.2017.1325692. 


\section{Annex V Conciliation: Case Analysis of Timor-Leste-Australia Conciliation Process} Mandatory conciliation under Annex V, Section 2 is to be initiated where a party has exercised its right to exclude disputes relating to sea boundary delimitation from compulsory arbitration and judicial settlement. Annex V, Section 2 comprises four Articles (Articles 11-14). Unfortunately, the UNCLOS's imprimatur on compulsory or mandatory conciliation is couched in hortatory language laid down at Article 11(1) which provides: "Any party to a dispute which, ... , section 3 may be submitted to conciliation under this section, may institute the proceedings by written notification addressed to the other party or parties to the dispute." [Emphases added] Arguably, the provision refers to the Party to the dispute. Such permissive language is followed in Article 11(2) by mandatory terms that state: "Any party to the dispute, notified under paragraph 1, shall be obliged to submit to such proceedings." [Emphasis added].

The UNCLOS also fails to meet the audi alteram partem requirement in Article 12 (Failure to reply or to submit to conciliation), which provides: "The failure of a party or parties to the dispute to reply to notification of institution of proceedings or to submit to such proceedings shall not constitute a bar to such proceedings." [Emphasis added]

Annex V, Section 2 of the UNCLOS arose for consideration by the PCA ${ }^{79}$ when Timor-Leste instituted an ad hoc conciliation against Australia in the Timor-LesteAustralia Conciliation Process Case, on April 11, 2016 by way of a "Notification Instituting Conciliation under Section 2 of Annex V of UNCLOS" Australia pursuant to Article 298 and Annex V of the Convention. On May 2, 2016, Australia submitted "Australia's Response to the Notice of Conciliation." conciliation aimed to delimit a permanent EEZ/Continental Shelf boundary with Australia under Articles 74 and 83 of the UNCLOS. Australia entered a Declaration on March 22, 2002 ousting Part XV options of the Convention for maritime boundary disputes. ${ }^{82}$

The Commission had to decide three matters at the outset: (1) concerning its competence in compulsory conciliation under Section II of Annex V of the Convention; (2) whether any issue of admissibility or comity arising under any other

79 PCA Case No. 2016-10, supra note 73.

80 Id.

81 Annex 7. Press Releases Nos. 1 to 3, Conciliation between the Democratic Republic of Timor-Leste and the Commonwealth of Australia, The Hague, July 29, 2016, https://pcacases.com/web/sendAttach/2335.

82 Supra note 73. For details, see Conciliation between Timor-Leste and Australia, Decision on Australia's Objections to Competence, https://pcacases.com/web/sendAttach/10052, supra note 73. 
convention precluded the Commission from continuing its proceedings; and (3) the date on which the 12-month period commenced to run for the conciliation procedure. Australia argued at paragraph 104 that Annex V was divided into voluntary and compulsory conciliation, including some reconciliation. ${ }^{83}$ Article 13 of Section 2 raised a competence challenge and Article 14 which is in Section 2, made Section I subject to Section 2. Australia further added that: "Articles 2-10 of Section I of this Annex apply subject to this Section [II]." 84 The Tribunal held:

106. Although these proceedings arise by way of a compulsory conciliation, Annex $\mathrm{V}$ itself is not principally concerned with compulsory proceedings. Article 284 of the Convention makes available voluntary conciliation within the general provisions described in Section 1 of Part XV. Section 1 of Annex V, which makes up the majority of the Annex, falls under the heading "Conciliation Procedure Pursuant to Section 1 of Part XV," and it is in this Section of Annex V that Article 7 and its 12-month deadline are to be found. Compulsory conciliation, in contrast, is structurally separated into the brief Section 2 of the Annex that provides for the resolution of disagreements over competence and further that procedures of Section 1 apply to a compulsory conciliation "subject to this section.".85

The Commission unanimously decided that it was competent with respect to the compulsory conciliation of the matters set out in Timor-Leste's Notification Instituting Conciliation under Section 2 of Annex V of the UNCLOS on April 11, 2016. There were no issues of admissibility or comity that precluded the Commission from continuing these proceedings. The 12-month period in Article 7 of Annex V of the Convention was to run from the date of this Decision. ${ }^{86}$ The conclusions and recommendations of the Conciliation Commission, however, were not binding on the parties. ${ }^{87}$

The Preamble to the Rules of Procedure in the Timor-Leste/Australia Conciliation Process Case requires States Parties to: (1) adhere to the UNCLOS; (2) acknowledge that Article 298(1) of the Convention permits a State to declare in writing that it does not accept any one or more of the procedures provided for the settlement of disputes mentioned in section 2; and (3) note that Section 2 refers to disputes concerning the interpretation or application of Articles 15, 74 and 83 relating to sea boundary

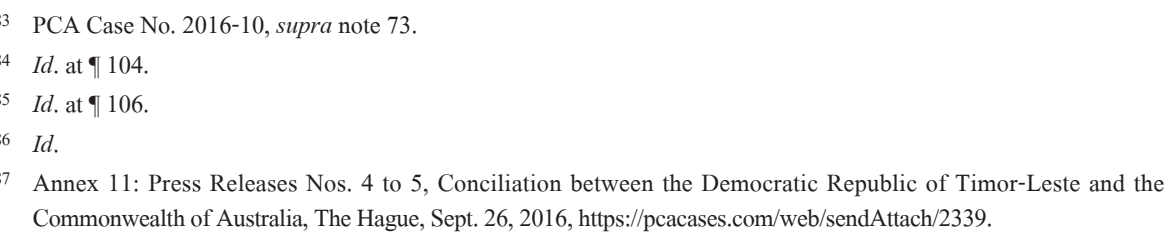


delimitations, or those involving historic bays or titles.

Article 298(1) further provides that "a State having made such a declaration shall, ... , accept submission of the matter to conciliation under Annex V, Section 2 ..." The Preamble recalls Article 11(1) of Annex V. On March 22, 2002, Australia issued a Declaration stating, inter alia, that "it does not accept any of the procedures provided for in Section 2 of Part XV ... with respect to disputes concerning the interpretation or application of Articles 15, 74 and 83 relating to sea boundary delimitations as well as those involving historic bays or titles."

Under Article 3 of Annex V to the UNCLOS, on June 25, 2016, the Conciliation Commission was constituted. The Conciliation Commission determined its own procedure under Article 4 of Annex V to the Convention. For adopting the Rules of Procedure, the Conciliation Commission met with the Parties at the PCA in The Hague, on July 28, 2016. Australia argued that the Commission lacked competence as the States Parties had concluded the 2006 Treaty on Certain Maritime Arrangements in the Timor Sea. Timor-Leste disagreed. The Commission ruled that the conciliation procedure was established pursuant to Article 298 and accordingly the competence of the Commission derives from the Convention and its Annex V, and not from any other Treaty.

\section{Proposed Amendments to Conciliation in Part XV, Section 1-General Provisions, and Annex V, Sections I \& II}

The UNCLOS only promotes a 'hortatory' type of mandatory conciliation in Section II of Annex V. Article 11(1) should be amended as follows: "Every Party to a dispute [that ousts the dispute settlement provisions of this Convention through Declarations or Statements] shall submit the dispute to compulsory conciliation under Annex V, Section 2." [Emphasis added] Alternatively, Annex V should refer to mandatory conciliation for all disputes. Similar amendments may also be made to Part XV, Section 1, Article 284. The 2002 ASEAN-China Declaration on Conduct of Parties in the South China Sea (ASEAN-China DOC) did not preclude, under Articles 281 or 282 of the UNCLOS, recourse to Section 2 of Part XV of the UNCLOS. 


\section{The Comity and Conciliation Commission for the South China Sea Disputes}

\section{A. Legal Grounds}

The SCS States have entered into a multilateral instrument(s) for the peaceful conduct of relations in the South China Sea. In spite of the ASEAN-China DOC adopted on November 4, 2002, the South China Sea tensions have not been eased between the two sides. Article 4 of the Declaration affirms to settle their "territorial and jurisdictional disputes by peaceful means, ... , in accordance with universally recognized principles of international law, including the UNCLOS." In Article 5 of DOC, the Parties "undertake, ... , to intensify efforts to seek ways, ... , to build trust and confidence between and among them, ..."

The Parties are working on a new binding agreement for the South China Sea. However, the status of this instrument is uncertain to this day. Given the current constraints in the UNCLOS to ameliorate the South China Sea tensions, a mandatory Partnership in Comity and Conciliation fostering congeniality, goodwill and cooperation in a win-win situation is considered here. Inferring from Cot's views above and recognizing the provenance of conciliation in international law, an examination of the possible juridical balancing of the maritime conflicts and tensions in the SCS is vital. Cot argues that bilateralism is not the way forward where the dispute is not isolated. ${ }^{88}$ In this regard, it may be argued that bilateralism is not an option in the road ahead even if the current conflicts do not spread. ${ }^{89}$

Conciliation in the proposed Partnership takes account of its pre- and postWorld War II origins in the UN Charter and the 1961 Convention that established Commissions of Inquiry and the Commission on Conciliation to settle the facts and propose solutions through an impartial and conscientious investigation. ${ }^{90}$ Furthermore, conciliation in the proposed Partnership builds on State consent in (a) Article $282^{91}$ and Annex V of the UNCLOS; (b) the principles of willingness to

88 Cot, supra note 61 , at 15.

89 Id. In the Jan Mayen Conciliation, the rights of third States were not affected. See Conciliation Commission on the Continental Shelf area between Iceland and Jan Mayen: Report and recommendations to the governments of Iceland and Norway, Decision of June 1981, 27 Reports of International Arbitral Awards (June 1981), https://legal.un.org/riaa/ cases/vol_XXVII/1-34.pdf.

90 U.N. Charter arts. 33 \& 36; 1961 Regulations on the Procedure of International Conciliation, art. 1; Vienna Convention on the Law of Treaties, art. 1.

91 UNCLOS art. 282. 
conciliate and importance of timelines of compulsory conciliation as enunciated in the Timor-Leste-Australia Conciliation Commission in its Report under Paragraph 108 mentioned above; and (c) Articles 4 and 5 of the ASEAN-China DOC.

The proposed Partnership is a mandatory, peaceful, consensual, iterative, adaptive, non-aggravating, and equitable ${ }^{92}$ solution, where the underlying leitmotiv is to establish facts and propose solutions within this comity of nations. It is hoped to foster regional inter-State goodwill, cooperation and congeniality that may promote a win-win situation for all SCS States. The Partnership will reduce the unassailable points of States; overcome any likely weakness in the argument of States; and promote its work. ${ }^{93}$ The Partnership Decision could be a judicial settlement, if the State parties follow the ad hoc Timor-Leste-Australia conciliation procedure. Or, as Cot advises, the decision may be considered not binding States Parties. At the very least, it serves as a prelude to international dispute settlement.

\section{B. Personal and Geographical Scope}

The Partnership applies to the SCS States and the South China Sea tensions and conflicts. The first instrument of its kind for the region, it will be a blend of tactful Asian diplomacy and dispute settlement mechanism. As a dispute settlement mechanism, the Partnership will require a Comity and Conciliation Commission. The UNCLOS's Annex V, Articles 2 and 3 may apply here with slight modifications. These modifications are to place emphasis on eminent Asian conciliators who may be high ranking diplomats or publicists. Similarly, provisions of Article 3 on involvement of the UN Secretary-General is optional, as States Parties may agree on this point. The total number of conciliators need not be confined to five.

Furthermore, Article 2 of Annex VIII (Special Arbitration on "Lists of experts") underscores the importance of experts from the FAO, UNEP, IOC, and IMO to be involved in disputes to determine the scientificity of the subject matter and improve the outcome of disputes. Managed by States Parties, different disputes may require different approaches and methods for settlement, and accordingly procedures and

North Sea Continental Shelf (F.R.G. v. Den.; F.R.G. v. Neth.), Judgement, 1969 I.C.J. Rep. 3 (Feb. 20), https:// www.icj-cij.org/public/files/case-related/52/052-19690220-JUD-01-00-EN.pdf.

93 Memorial of Philippines, South China Sea Arbitration (Phil. v. P.R.C.), PCA case Repository No. 2013-19 (vol. XI), annex LA-47 (Joint Separate Opinions of Judges Wolfrum and Kelly), 9 . For all PCA documents on the South China Sea Arbitration, see PCA, The South China Sea Arbitration (Phil. v. P.R.C.), https://pca-cpa.org/en/cases/7. For Volume XI in particular, see Arbitration under Annex VII of the United Nations Convention on the Law of the Sea, Supplemental Written Submission of the Philippines, Mar. 16, 2015, https://files.pca-cpa.org/pcadocs/The\%20 Philippines $\% 27 \% 20$ Supplemental $\% 20$ Written $\% 20$ Submission $\% 20-\% 20$ Volume $\% 20 X I \% 20 \% 28$ Annexes $\% 20543$ $573 \% 29$.pdf. 
rules may be substituted. Once conciliation is completed and, if joint development of resources is envisaged, States Parties can decide on the legal mechanism and equity participation for sustainable joint development of the seas. A neutral Secretariat should be established for this purpose.

\section{Material Scope}

Article 4 of Annex V allows States Parties to determine their own procedure. Similarly, fact-finding by States Parties to reach a consensus on what is in dispute may be set out in an instrument as provided in Article 5 of Annex VIII on Special Arbitration. States Parties should agree on the mandate of the Comity and Conciliation Commission, the list of disputes and applicable legal and scientific criteria, and rules of procedure and evidence. The material scope may include the "six flexible rules" set out in Annex V on the commencement of conciliation proceedings, report, termination, institution of proceedings, failure to reply or to submit to conciliation, and compliance.

Lawrence Collins points out that in a conciliation, where necessary, the inherent jurisdiction and capacity to issue provisional measures or injunction for the protection of rights of States Parties to prevent further irreparable and prejudicial harm are powers that need to be expressly mentioned in the constituent instrument of the Conciliation Commission or in its Rules of Procedure. ${ }^{94}$ Where such an approach is desired, this will give the Comity and Conciliation Commission powers of a regular court, as was the experience of the Inter-American Commission on Human Rights. ${ }^{95}$ The material scope may also address a good scientific approach as the South China Sea is a large marine ecosystem. For example, in determining the status of islands, many scientific criteria may be considered.

The role of evidence-based scientific proof to establish principles of causation of marine environmental degradation, sustainable development of the coastal communities, baselines figures and statistical declines in baseline figures, standards for land reclamation, proof of wrongdoing, the principles of liability, causation, burden of proof, role of defenses, and liability and compensation, could be addressed. For fisheries protection and law enforcement, international intergovernmental organizations, for example, FAO and IMO, respectively, could be called for expert evidence. If provisional measures are sought, it would be then important to examine

\footnotetext{
94 See 3ème commission, Provisional Measures, Mesures provisoires, Rapporteur: Lord Collins of Mapesbury, Final Report: Dec. 23, 2016, https://www.idi-iil.org/app/uploads/2017/06/3eme_com.pdf. 
the admissibility of proof of facts. ${ }^{96}$ Novel principles of fiduciary relationship in environmental matters could also be considered.

A Comity and Conciliation Decision should assist the contending States to narrow and iron out their differences at the very least. The Comity and Conciliation Commission should by its very constitution be vested with subject-matter jurisdiction $a b$ initio, as the States Parties desire to conciliate and are agreed on the disputes. The Comity and Conciliation Commission should also be vested with the necessary jurisdiction to proceed to the merits of the dispute and implement the decision where conciliation has proven successful. ${ }^{97}$ Articles 4 to 10 of Annex V may be applicable here in matters of choice of procedure, amicable settlement, a binding final report, notice and other budgetary matters. It is envisaged that States Parties adopt a Comity and Conciliation Instrument such as an Agreed Text or Memorandum where they set out question(s) of fact and law that need a solution on a win-win basis. Article 11 of Annex V, Section 2 states that a written notice is sufficient to commence conciliation proceedings for a Section 3 dispute.

Article 12 of Annex V on failure to reply or submit to conciliation is not suitable here as it violates the spirit of good neighbourly relations. Article 13 deals with competence de la competence and Article 14 affirms the application of Articles 2 to 10 of Sections 1 of Annex V. The Asian International Arbitration Centre in Kuala Lumpur, which is a hearing centre for the PCA, could also act as the venue of the proposed Partnership and its Commission for regional ocean disputes. ${ }^{98}$

\section{Temporal and Fiscal Scope}

A time frame of specified duration such as a 12-month period for reporting may be acceptable to the Comity and Conciliation Commission as was seen in the TimorLeste-Australia Conciliation Process. However, States Parties must agree on disputes and may consider whether there is to be prescription of time bars. ${ }^{99}$ The report, conclusion and recommendations or findings ought to be mandatory and complied

MOX Plant (Ir. v. U.K.), Provisional Measures, Case No. 10, Order of Dec. 2001, ITLOS rep. 95, at 110, ๆ https:// www.itlos.org/fileadmin/itlos/documents/cases/case_no_10/published/C10-O-3_dec_01.pdf.

97 Collins, supra note 99 at 343.

98 GAR Hearing Centres Survey, Nov. 3, 2015-the KLRCA has the potential to be the best outside the Peace Palace (Global Arbitration Review Guide to Regional Arbitration (vol. 6/2018)), https://globalarbitrationreview.com/ survey/the-guide-regional-arbitration/2021/organization-profile/asian-international-arbitration-centre-aiac; Bangunan Sulaiman: The AIAC's State of the Art Facilities to Conduct Arbitration Hearings, Asian International Arbitration Centre (Oct. 4, 2018), https://www.aiac.world/news/267/Bangunan-Sulaiman:-The-AIAC\%E2\%80\%99s-State-of-theArt-Facilities-to-Conduct-Arbitration-Hearings.

99 P. Sanders, The Work of UNCitral on Arbitration and Conciliation 305 (2004). 
with by the States Parties. Article 8 of Annex V provides that the conciliation proceedings are terminated when a settlement has been reached. A settlement is deemed to have been reached when any one of three things happen when: (1) the Parties have accepted; (2) one Party has rejected the recommendations of the report addressed to the UN Secretary-General; or (3) a period of three months has elapsed from the date of transmission of the report to the Parties.

The results of the deliberations of the States Parties should preferably be publicized by the Comity and Conciliation Commission as decided by the States. However, given the nature of the dispute, this is an optional decision by the States Parties, considering domestic politics, international relations, and third-party interest. It should be mandatory for all States Parties to accept the recommendations. The fiscal scope examines related budgetary matters. Once the Partnership in Comity and Conciliation for the South China Sea is established, States could examine their maritime entitlements in the South China Sea under the UNCLOS and relevant rules of international law. The States to the dispute concerned may fund the deliberations.

\section{Conclusion}

The audi alteram partem rule in Annex VII of the UNCLOS needs to be amended to make ex-parte arbitration hearings appealable, for example, to the ITLOS or the ICJ. Absent such an amendment, with its provenance rooted in international law and with Asia on the rise, the implementation of the proposed Partnership in Comity and Conciliation makes it plausible that for the most part, the South China Sea region must pursue a common solution through multilateral negotiations, to establish a peaceful, cooperative and benefit-for-all order for certain specific and technical issues. ${ }^{100}$ The SCS Case confirms the Philippines' queries on maritime entitlements of certain maritime features and consequently concerns both States' compliance with the decision. Rosenne points out: "If non-compliance with the decision becomes a threat to the peace, the normal peace-maintenance machineries, especially those of Chapters VI and VII of the Charter can be invoked." ${ }^{101}$ Finally, the immediate res

100 See reason given by the Agent for the Philippines to the Tribunal in the jurisdictional phase why it chose to commence these proceedings. See Reichler, supra note 27. For criticisms of the SCS Case, see supra note 23, at 200-10. It states: "(3) The Tribunal erroneously narrowed the obligation to exchange views under the Convention to that concerning merely the means of dispute settlement."

101 Rosenne, supra note 52, at 66. 
296 Mary George \& Anneliz R. George

judicata implication ${ }^{102}$ of the SCS Case is that another contentious proceeding before the ICJ on the same grounds cannot be instituted. ${ }^{103}$

Received: August 1, 2021

Modified: September 30, 2021

Accepted: November 1, 2021

102 For the implications of res judicata for dispute settlement, see X. HANQIN (ED.), JuRisdiction of the INTERNATIONAL Court of Justice 130-2 (2017).

103 Id. at 81-90. 